\title{
FAKTOR-FAKTOR PENENTU STRUKTUR MODAL DENGAN UKURAN PERUSAHAAN SEBAGAI VARIABEL MODERASI
}

\author{
Nur Fitriyanto(1), \\ UIN Sunan Kalijaga Yogyakarta \\ nur.fitriyanto@uin-suka.ac.id \\ Slamet Haryono ${ }^{(2)}$ \\ UIN Sunan Kalijaga Yogyakarta, Indonesia
}

\begin{abstract}
Management policy in determining capital structure is one example of a vital policy in managing a company. Many companies expect to have an optimal capital structure to maximize the profits of shareholders. The purpose of this study is to examine the influence of several determinants of capital structure, such as business risk, growth opportunities, non-debt tax shields, sharia compliance, profitability and tangibility to corporate leverage moderated by company size. The population of this study were companies that have entered the IDX30 index criteria, with a purposive sampling method obtained by a sample of 14 companies. Test equipment used in this study uses panel data regression and Moderated Regression Analysis (MRA). The findings of this study in model I are profitability and non-debt tax shields have a significant negative effect on corporate leverage, firm size has a significant positive effect on company leverage, business risk has a significantly positive effect on firm leverage. Meanwhile, sharia compliance, growth opportunities and tangibility are not significant. The findings of model II found that only the variable non-debt tax shields and tangibility are able to be moderated by company size.
\end{abstract}

Keywords: Struktur Modal, Kepatuhan Syariah, Profitability, Tangibility, Growth Opportunity, Business Risk, Non-debt Tax Shield dan Ukuran perusahaan 


\section{PENDAHULUAN}

Dalam rangka mempertahankan dan meningkatkan eksistensi bisnis, perusahaan dituntut untuk cerdas dalam memilih keputusan terkait strukutr modalnya. Manajemen dalam suatu perusahaan mengambil peran penting untuk menentukan proporsi struktur modal guna memaksimalkan nilai seuatu perusahaan. Namun, dalam pemilihan ini bukanlah suatu pekerjaan yang mudah dalam memilih sumber hutang dan pemilihan ekuitas, mengingat dalam setiap keputusan yang diambil akan menimbulkan biaya dan manfaat masing-masing akibat dari pemilihan proporsi struktur modal ini. Sedikit kesalahan dalam pemilihan struktur modal ini, akan berakibat pada keseimbangan bisnis bahkan bisa mengakibatkan kebangkrutan dari perusahaan yang ceroboh dalam menentukan proporsi ini.

Modigliani dan Miller (1958) merupakan pelopor dalam pengembangan teori struktur modal. Teori ini mengatakan bahwa penggunaan hutang dalam strukutr modal tidak akan mempengaruhi nilai perusahaan. Namun, teori mereka ini mendapatkan kritikan hebat dari berbagai pihak, sehingga akhirnya pada tahun 1963, Modigliani dan Miller (1963) kembali mengajukan teori struktur modal dengan memperhitungkan pajak. Pelibatan pajak dalam struktur modal akan memberikan pengaruh positif terhadap nilai perushaan. Biaya bunga karena penggunaan hutang akan mengurangi laba sebelum pajak, sehingga saat pajak diperhitungkan maka akan menjadi penghematan pajak (tax saving), pajak yang kecil otomatis akan meningkatykan nilai perusahaan.

Sejak saat itu, banyak peneliti mengikuti jalur MM (1958) untuk mengembangkan teori baru tentang struktur modal. Inkonsistensi dalam beberapa penelitian masih ditemukan dalam penentuan faktor penentu struktur modal (Haron, 2014) dan Rajan dan Zingales (1995) dalam penelitiannya menyatakan bahwa faktor-faktor penentu struktur modal belum bisa terpecahkan, sehingga masih menjadi dilema perusahaan dalam menentukan struktur modal yang optimal.

Penelitian mengenai struktur modal telah banyak dilakukan oleh beberapa peneliti, namun dari penelitian-penelitian tersebut masih memberikan hasil yang tidak konsisten atau bervariasi. Malinic (2013) halaman 110-113, melaporkan hasil penelitian yang sama dengan Nadeem dan Wang (2011) halaman 129-130, mereka menyatakan bahwa profitabilitas, likuiditas, dan tangibilitas yang tinggi akan membuat tingkat hutang semakin rendah atau dengan kata lain profitabilitas, likuiditas, volatilitas laba, dan tangibilitas berpengaruh negatif terhadap leverage perusahaan, sesuai dengan penelitian oleh Booth et al (2001) pada halaman 118, bahwa ketika tangibilitas aset perusahaan meningkat, meskipun rasio utang jangka panjang meningkat, rasio utang total turun; itu adalah, substitusi jangka panjang untuk hutang jangka pendek kurang dari satu tahun. Hasil untuk tangibilitas bertentangan dengan penelitian oleh M'ng et al. (2017) pada perusahaan Malaysia dan Singapura, menurutnya tangibilitas yang tinggi maka leverage perusahaan meningkat pula, penelitian itu sejalan dengan penelitian Rajan \& Zingales (1995) pada halaman 1451 dan Esperanca et al (2003) pada halaman 69 , yakni tangibilitas berhubungan positif terhadap leverage perusahaan di negara maju.

Wald (1999) dan Deesomsak et al. (2004) sejalan dengan proposal DeAngelo dan Masulis (1980) pada halaman 27, DeAngelo dan Masulis (1980) berpendapat bahwa mengatakan perusahaan dapat mengganti perisai pajak dari pembiyaan mereka dengan manfaat pajak dari depresiasi dan kredit pajak investasi. Oleh karena itu, perusahaan yang memiliki depresiasi aset tinggi, maka penggunaan perisai pajak atas pembiyaan akan lebih kecil, sehingga struktur modal akan lebih rendah. Namun, Titman dan Wessels (1988) pada halaman 17 menyatakan bahwa penelitiannya tidak menemukan pengaruh anatara perisai pajak non hutang terhadap rasio hutang.

Pada variabel ukuran perusahaan juga terdapat variasi hasil penelitian, 
penelitian oleh Nadeem dan Wang (2011), M'ng et al. (2017) dan Ilyukhin (2017) mengatakan bahwa ukuran perusahaan berpengaruh positif terhadap struktur modal sedangkan Carolina (2015) dan Sahudin et al. (2019) berbeda pendapat, temuan mereka melaporkan bahwa ukuran perusahaan berpengaruh negative terhadap struktur modal perusahaan, lain halnya dengan Viviani (2008) pada halaman 182, bahwa ukuran perusahaan tidak berpengaruh terhadap leverage perusahaan.

Penelitian yang secara khusus mengangkat isu dari industri keuangan Islam masih terbatas. Menurut teori keuangan Islam, perusahaan yang mematuhi syariah, patuh pada berbagai aturan untuk mempertahankan praktik mereka; perusahaan non syariah tidak tunduk pada batasan seperti itu (Ahmed, 2009). Penelitian ini akan menarik karena mempertimbangkan aturan-aturan terkait kepatuhan syariah yang menurut Alnoria dan Alqahtani (2019) bahwa kepatuhan syariah memainkan peran penting dalam menentukan keputusan struktur modal.

Beberapa studi teoritis dan empiris yang dilakukan telah menyelidiki faktorfaktor penentu struktur modal untuk memahami pilihan perusahaan untuk memutuskan pembiayaan hutang atau ekuitas. Singkatnya, sebagian besar studi di atas berfokus pada perusahaan tanpa memasukkan unsur kepatuhan syariah. Seiring dengan meningkatnya jumlah perusahaan yang bersaing secara syariah dan dengan pesatnya pertumbuhan pasar modal Islam, maka penting untuk menyelidiki faktor-faktor penentu keputusan struktur modal dengan memasukkan variabel kepatuhan syariah, mengingat ada kriteria-kriteria peraturan yang berbeda yang diberlakukan oleh DSNMUI di pasar modal Indonesia.

\section{KAJIAN PUSTAKA DAN PENGEMBANGAN HIPOTESIS}

Teori Modigliani dan Miller
Modigliani dan Miller (1958) telah memulai penelitian tentang struktur modal dan hubungannya dengan nilai perusahaan. Pada kondisi pasar yang efisien (tidak ada pajak, biaya keagenan dan kebangkrutan, asimetri informasi), nilai pasar perusahaan tidak dipengaruhi pada pilihan struktur modalnya sedangkan biaya modal perusahaan sepenuhnya tergantung pada risiko bisnis. Struktur modal dan keputusan pembiayaan dianggap tidak relevan dalam meningkatkan nilai pemegang saham, dengan demikian tidak ada struktur modal yang optimal. Teori yang diajukan MM ini, banyak menuai kritikan dari berbagai pihak, karena asumsinya dirasa tidak masuk akal

\section{Teori Trade Off}

Trade off theory mengatakan bahwa struktur modal yang optimal akan tercapai ketika manfaat dari alokasi penggunaan hutang seimbang dengan pengorbanan dari alokasi penggunaan hutang tersebut. Manfaat dari penggunaan utang berupa penghematan pajak (tax shield) sedangkan pengrobanan dari penggunaan hutang berupa beban bunga, biaya kebangkrutan dan biaya agensi (Myers, 2001). Hal ini sejalan dengan yang diuangkapkan ole Scott (1977), perusahaan masih diperkenankan mengalokasikan hutang namun ada batasan ketika cost of bankcrupty sudah setara dengan manfaat dari tax savings, maka porsi hutang harus dihentikan.

\section{Teori Pecking Order}

Myers dan Majluf pada tahun 1984 mengembangkan sebuah teori yang telah diperkenalkan oleh Donaldson pada tahun 1961. Teori ini menyarankan kepada manajer untuk menggunakan dana dari dalam perusahaan terlebih dahulu karena tidak terdapat asymmetric information dan biaya transaksi, sehingga perusahaan yang menggunakan dana dari dalam perusahaan memiliki tingkat profitabilitas yang tinggi dibandingkan dengan perusahaan yang menggunakan dana dari luar perusahaan. Informasi asimetris, juga dikenal sebagai kegagalan distribusi informasi, terjadi ketika satu pihak memiliki lebih banyak informasi (lebih baik) daripada pihak lain, 
yang menyebabkan ketidakseimbangan kekuatan transaksi.

Dalam konteks teori pecking order, bahwa tidak ada struktur modal yang optimal, namun teori ini menyarankan pada preferensi dalam penggunaan sumber pendanaan. Myers dan Majluf (1984) menngungkapkan urutan perusahaan untuk menggunakan sumber pendanaan dimulai dari laba ditahan (retained earnings), penggunaan laba ditahan akan memudahkan menyelesaikan maslaah asimteri informasi, kemudian jika laba ditahan tidak tersedia maka menggunakan sumber pendanaan eksternal yaitu utang, jika utang tidak mencukupi atau tidak memungkinkan maka selanjutnya menggunakan cara penerbitan saham baru.

\section{Metode Skrining Saham Syariah di Indonesia}

Pemilihan saham syariah di Indonesia mengalami beberapa kali perubahan. Pada tahun 2001, Dewas Syariah Nasional memberikan kriteria bagi saham yang masuk dalam kategori saham syariah hanya berdasarkan satu kriteria, yaitu perusahaan tersebut bergerak atau beroperasi pada bidang yang tidak bertentangan dengan prinsip syariah untuk bisa masuk ke kelompok indeks JII (Jakarta ISlmaic Index). Pada tahun 2007 saat kemunculan Daftar Efek Syariah (DES), kriteria yang digunakan adalah menggunakan rasio keuangan, yaitu rasio hutang terhadap ekuitas dengan batasan tidak boleh melebih $82 \%$. Kriteria kembali mengalami revisi pada tahun 2012, dimana rasio yang digunakan tidak lagi menggunakan rasio hutang tehadap ekuitas, namun menajdi rasio hutang terhadap asset dan berlaku sampai saat ini. Kriteria itu juga ditambah dengan prinsip perusahaan tidak boleh beroperasi pada kegiatan yang bertentangan dengan syariat serta pendapatan dari non halal tidak boleh melebih $10 \%$.

\section{Review Penelitian Terdahulu}

Akinsomi et al. (2015) dan Naz et al. (2017) sepakat bahwa ada perbedaan yang signifikan ketika keputusan pembentukan struktur modal antara perusahaan yang patuh terhadap syariah dengan perusahaan yang non syariah. Alnoria dan Alqahtani (2019) dengan sampel perusahaan dari Arab Saudi menemukan bahwa kepatuhan syariah memainkan peran penting dalam menentukan keputusan struktur modal. Secara khusus, perusahaan yang mematuhi syariah memiliki tingkat leverage yang lebih rendah dan penyesuaian kecepatan lebih rendah secara signifikan yang diukur oleh proksi book dan market dari struktur modal daripada perusahaan non-syariah. Penelitian ini mendukung penelitian yang dilakukan oleh Farooq and Tbeur (2013) dimana mereka mengemukakan bahwa perusahan syariah lebih berani membayar dividen lebih tinggi daripada yang non syariah. Hal ini dapat dijelaskan karena perusahaan non syariah juga memiliki tingkat leverage perusahaan yang lebih rendah daripada perusahaan non syariah.

$$
\text { Nadeem dan Wang (2011) }
$$

melakukan penelitian di Bursa Efek Pakistan menunjukkan bahwa profitabilitas, likuiditas, volatilitas laba, dan tangibilitas (struktur aset) berpengaruh negatif dengan rasio utang, sedangkan ukuran perusahaan berpengaruh positif dengan rasio hutang. Non-debt tax shield dan peluang pertumbuhan tampaknya tidak terkait secara signifikan dengan rasio utang. Hasil yang sama ditunjukkan oleh Malinić et al. (2013) yang melakukan studi dengan sampel perusahaan - perusahaan dari Serbia, mengatakan bahwa ada dampak negatif yang signifikan dari likuiditas, tangibilitas, profitabilitas dan kesenjangan kas pada dua rasio utang. Leverage secara signifikan dipengaruhi oleh volatilitas pendapatan dan peluang pertumbuhan perusahaan Serbia. Carolina (2015) dalam penelitiannya di Bursa Efek Indonesia sepakat bahwa profitabilitas, ukuran perusahaan berpengaruh negatif terhadap leverage perusahaan yang mendukung teori pecking order dan sementara itu, peluang pertumbuhan dan leverage perusahaan berhubungan negative yang selaras dengan teori trade off statis dan teori biaya agensi.

Di bursa Rusia, Ilyukhin (2017) melaporkan bahwa penentu struktur modal yang paling signifikan dari perusahaan 
Rusia adalah leverage rata-rata industri, ukuran perusahaan dengan efek positif dan peluang pertumbuhan dengan efek negatif. Profitabilitas, non-debt tax shield, dan kondisi pasar saham dengan efek negatif dampaknya kurang signifikan. Risiko bisnis, peluang pertumbuhan yang diukur sebagai belanja modal untuk total aset, tangibilitas aset, keunikan aset, tarif pajak rata-rata, kelompok industri perusahaan energi, pinjaman dan tingkat inflasi adalah faktor penentu yang tidak signifikan. Sahudin et al. (2019) sepakat dengan Ilyukhin (2017), bahwa faktor-faktor spesifik perusahaan seperti efisiensi berpengaruh positif, risiko kebangkrutan, profitabilitas, tangibilitas, likuiditas dan ukuran perusahaan berpengaruh negative signifikan dalam mempengaruhi keputusan pembiayaan perusahaan di Malaysia.

M'ng et al. (2017) melibatkan investigasi dari tiga bursa negara yaitu Malaysia, Singapura dan Thailand, mereka juga melaporkan bahwa profitabilitas memiliki pengaruh negatif yang signifikan terhadap modal struktur untuk Malaysia dan Singapura tetapi tidak signifikan untuk Thailand. Sementara ukuran perusahaan memiliki pengaruh positif yang signifikan terhadap struktur modal untuk semua negara. Temuan mereka juga menunjukkan bahwa tangibilitas aset memiliki pengaruh positif signifikan terhadap modal struktur untuk Malaysia dan Singapura sementara tidak signifikan untuk Thailand. Depresiasi total aset menunjukkan pengaruh negatif pada struktur modal di semua tiga negara.

Oleh karena itu penelitian ini, berusaha menambah beberapa pengetahuan dalam literatur dengan secara empiris menguji faktor-faktor penentu struktur modal di Indonesia dengan memasukkan variabel kepatuhan syariah dalam model serta menyertakan ukuran perusahaan sebagai variabel moderasi.

\section{Pengembangan Hipotesis Struktur Modal}

Dalam penelitian ini, struktur modal diukur dengan menggunakan total debt yang berisi long term debt dan short term debt dibagi dengan total assets. Penelitianpenelitian yang dilakukan oleh Nadeem dan Wang, 2011; Buferna dan Hodgkinson, 2005; Hossain dan Ali, 2012; Milton dan Raviv, 1991; Rajan dan Zingales, 1995 telah menggunakan rasio ini.

\section{Kepatuhan Syariah}

Farooq and Tbeur (2013) melakukan investigasi rasio pembayaran dividen pada Negara MENA, mereka menyebutkan bahwa perusahaan yang patuh terhadap aturan syariah memiliki rasio pembayaran yang lebih tinggi, hal ini terungkap juga bahwa perusahaan yang patuh syariah memiliki rasio leverage yang rendah. Naz et al. (2017) melakukan penelitian pada perusahaan Inggris dan Pakistan untuk melihat pengaruh peran manager puncak terkait keputusan struktur modal, yang hasilnya menyatakan bahwa ada perbedaan yang signifikan antara perusahaan dengan kepatuhan syariah dengan perusahaan non syariah terhadap keputusan dalam pembentukan strukutr modal. Akinsomi et al. (2015) dalam penelitiannya mengatakan bahwa pembatasan-pembatasan pada sumber pendanaan struktur modal pada perusahaan syariah tentu akan berdampak pada tingkat leverage perusahaan.

Perusahaan yang mematuhi batasan - batasan syariah cenderung memilki kekakuan atau keterbatasan dalam mencari sumber pembiayaan. Batasan - batasan dalam screening syariah itu membatasi jumlah rasio utang dan pemilihan sumber pendanaan yang ahrus sesuai prinsip syariah. Hal ini akan mengakibatkan perusahaan memiliki rasio utang lebih rendah terhadap asset yang dimilkinya. Pernyataan ini didukung oleh penelitian dari Alnoria dan Alqahtani (2019), Farooq dan Tbeur, (2013), Naz et al., (2017) yang menyatakan bahwa kepatuhan syariah berpengaruh signifikan negatif terhadap book leverage.

\section{$\mathrm{H}_{1}$ : Kepatuhan Syariah memiliki pengaruh negatif signifikan terhadap book leverage.}

\section{Profitability}


Dalam teori trade-off diungkapkan bahwa antara profitabilitas dan leverage berhubungan positif, karena profitabilitas yang tinggi mendorong penggunaan hutang dan memberikan manfaat kepada perusahaan untuk mendapatkan pengamanan pajak dari pembayaran bunga. Teori pecking order mendalilkan bahwa perusahaan lebih suka menggunakan dana yang dihasilkan secara internal ketika tersedia dan memilih utang daripada ekuitas ketika pembiayaan eksternal diperlukan. Perusahaan yang memiliki profitabilitas tinggi, akan menggunakan laba ditahannya untuk membiayai perusahaan terlebih dahulu baru berhutang jika memungkinkan.

Dengan demikian, teori ini menunjukkan hubungan negatif antara profitabilitas (sumber dana internal) dan leverage. Beberapa studi empiris juga telah melaporkan hubungan negatif antara profitabilitas dan leverage (Toy et al., 1974; Titman dan Wessels, 1988; Rajan dan Zingales, 1995; Wald, 1999; Booth et al., 2001; Chen, 2004; Bauer, 2004; Viviani, 2008; Öztekin, 2015).

$\mathrm{H}_{2}$ : Profitabilitas memiliki pengaruh negatif signifikan terhadap book leverage.

\section{Tangibility}

Sebagian besar teori struktur modal berpendapat bahwa jenis aset yang dimiliki oleh suatu perusahaan dengan beberapa cara dapat mempengaruhi pilihan struktur modalnya. Teori trade off memprediksi hubungan positif antara leverage dan aset berwujud. Aset berwujud biasanya memberikan jaminan nilai relatif tinggi terhadap aset tidak berwujud, yang menyiratkan bahwa aset ini dapat mendukung lebih banyak utang. Aset berwujud mengurangi biaya financial distress.

Dengan demikian, semakin tinggi tangibilitas perusahaan maka kolateral yang dimiliki perusahaan juga lebih banyak, sehingga hal ini akan memacu perusahaan untuk berhutang lebih banyak lagi karena kualitas dan kuantitas jaminan asetnya. Pernyataan ini sesuai dengan hasil penelitian oleh (misalnya Jensen and Meckling, 1976; Titman and Wessels,
1988; Jensen et al., 1992; Rajan and Zingales, 1995; Chen et al., 1998; Bevan and Danbolt, 2001; M'ng et al., 2017; Sahudin et al., 2019).

$\mathrm{H}_{3}$ : Tangibilitas memiliki pengaruh positif signifikan terhadap book leverage.

\section{Growth Opportunity}

Jensen dan Meckling (1976), Myers and Majluf (1984), dan Fama and French (2000) berpendapat bahwa perusahaan dengan peluang pertumbuhan masa depan yang tinggi harus menggunakan lebih banyak pembiayaan ekuitas, karena perusahaan dengan leverage yang lebih tinggi lebih mungkin melewatkan peluang investasi yang menguntungkan. Menurut teori trade-off, perusahaan yang memiliki peluang pertumbuhan di masa depan, yang merupakan bentuk aset tidak berwujud, cenderung meminjam lebih sedikit daripada perusahaan yang memiliki aset lebih berwujud karena peluang pertumbuhan tidak dapat dijamin. Teori trade-off memprediksi hubungan negatif antara leverage dan peluang investasi. Teori pecking order juga menunjukkan bahwa pertumbuhan perusahaan berhubungan negatif dengan struktur modalnya. Peluang pertumbuhan dapat dianggap sebagai aset yang menambah nilai bagi perusahaan, tetapi tidak dapat dijamin dan tidak dikenai pajak penghasilan. Studi-studi ini melaporkan peluang pertumbuhan perusahaan berhubungan negative dengan struktur modal (Rajan dan Zingales, 1995; De Miguel dan Pindado, 2001; Bevan dan Danbolt, 2001).

\section{$\mathrm{H}_{4}$ : Growth Opportunity memiliki pengaruh negatif signifikan terhadap book leverage.}

\section{Business Risk}

Dalam trade off theory menyatakan perusahaan yang memiliki utang yang besar cenderung memiliki volatilitas pendapatan yang tinggi. Tingkat volatilitas yang tinggi akan meningkatkan business risk perusahaan. Peningkatan business risk perusahaan ini akan mengakibatkan meningkatnya cost of fund. Peningkatan cost of fund ini akan mendorong perusahaan untuk mengurangi penggunaan utang. Hal 
ini berarti perusahaan yang memiliki business risk yang tinggi akan menurunkan penggunaan utang. Artinya terdapat pengaruh negatif dari business risk terhadap struktur modal. penelitian ini didukung oleh penelitian yang dilakukan oleh (Furi dan Saifudin, 2012; Scott, 1977).

$\mathrm{H}_{5}$ : Business risk memiliki pengaruh negatif signifikan terhadap book leverage.

\section{Non-debt Tax Shield}

Beban bunga berkontribusi terhadap penurunan penghasilan kena pajak perusahaan. Tapi, ada juga metode yang lain mengurangi beban pajak perusahaan, yaitu perusahaan dapat mengganti perisai pajak dari pembiyaan mereka dengan manfaat pajak dari depresiasi dan kredit pajak investasi (DeAngelo dan Masulis, 1980, 27). Perusahaan yang memiliki perisai pajak non hutang (NDTS) akan cenderung mengurangi porsi mereka untuk melakukan hutang, karena manfaat dari perisai pajak telah dilakukan pada penyusutan dan amortisasi. Dengan semakin banyak atau tingginya nilai NDTS hal ini diharapkan akan menurunkan penggunaan hutang dalam struktur modal mereka. Bradley et al. (1984) mengatakan bahwa adanya hubungan langsung yang kuat antara leverage dan jumlah relatif perisai pajak bukan utang. Titman dan Wessels (1988) tidak menemukan dukungan untuk efek pada rasio utang yang timbul dari perisai pajak non-utang. Wald (1999) dan Deesomsak et al. (2004) melaporkan hubungan negatif yang signifikan antara leverage dan perisai pajak bukan utang. Pernyataan ini, berarti bahwa NDTS memiliki pengaruh negative terhadap hutang atau book leverage.

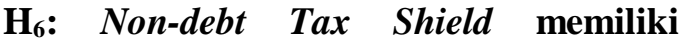
pengaruh negatif signifikan terhadap book leverage.

\section{Ukuran perusahaan}

Ukuran perusahaan yang besar, memungkinkan mereka untuk melakukan lini bisnis yang beragam. Dengan banyaknya lini bisnis yang terdiversifikasi, maka perusahaan dengan ukuran yang besar tidak mudah mengalami kebangkrutan, cost of fund perusahaan besar mejadi lebih murah alias rendah. Perusahaan ini pun cenderung memiliki total aset besar, semakin besar ukuran perusahaan maka semakin besar pula profitabilitas, aset berwujud, depresiasi aset, risiko bisnis, peluang tumbuh dimasa depan dan pertumbuhan penjualan perusahaan. Perusahaan yang besar juga memiliki pengaruh pada keputusan skrining syariah karena ada faktor aset yang besar didalamnya. Maka bisa disimpulkan bahwa ukuran perusahaan dapat memperkuat maupun memperlemah kepatuhan syariah, profitabilitas, tangibilitas, growth opportunity, business risk dan NDTS terhadap struktur modal.

$H_{8}$ : Ukuran perusahaan memoderasi hubungan antara kepatuhan syariah, profitabilitas, tangibilitas, growth opportunity, business risk dan NDTS terhadap book leverage..

\section{METODE PENELITIAN}

\section{Jenis Penelitian}

Penelitian ini termasuk penelitian kuantitatif yang berusaha menganalisis faktor-faktor penentu struktur modal dengan dimoderasi oleh ukuran perusahaan pada perusahaan yang konsisten terseleksi dalam indeks IDX30 sejak diluncurkan tahun 2012 sampai dengan tahun 2019.

\section{Populasi dan Sampel}

Populasi pada penelitian ini adalah perusahaan yang terdaftar pada indeks IDX30 sejak diluncurkan sampai dengan tahun 2019. Metode pengumpulan data pada penelitian ini adalah studi pustaka yaitu dimana dalam studi pustaka tersebut data dan teori yang diperoleh dari teori yang diperoleh dari artikel, literatur, jurnal dan hasil penelitian terdahulu yang relevan dengan penelitian dan landasan teori dan metode dokumentasi yaitu mengumpulkan data sekunder berupa laporan keuangan melalui website resmi Bursa Efek Indonesia yaitu www.idx.co.id maupun website perusahaan dari masing-masing sampel terpilih. 
Pengambilan sampel dilakukan metode purposive sampling. Dalam penelitian ini yang menjadi sampel yaitu perusahaan yang memenuhi kriteria tertentu. Adapun hasil pemilihan sampel sesuai kriteria yang dijadikan sebagai sampel penelitian ditampilkan pada tabel 1 . Penelitian ini dari hasil seleksi sampel menggunakan 14 perusahaan dengan periode waktu 8 tahun, sehingga sampel yang diperoleh 112 sampel.

Tabel 1

Hasil pemilihan sampel penelitian

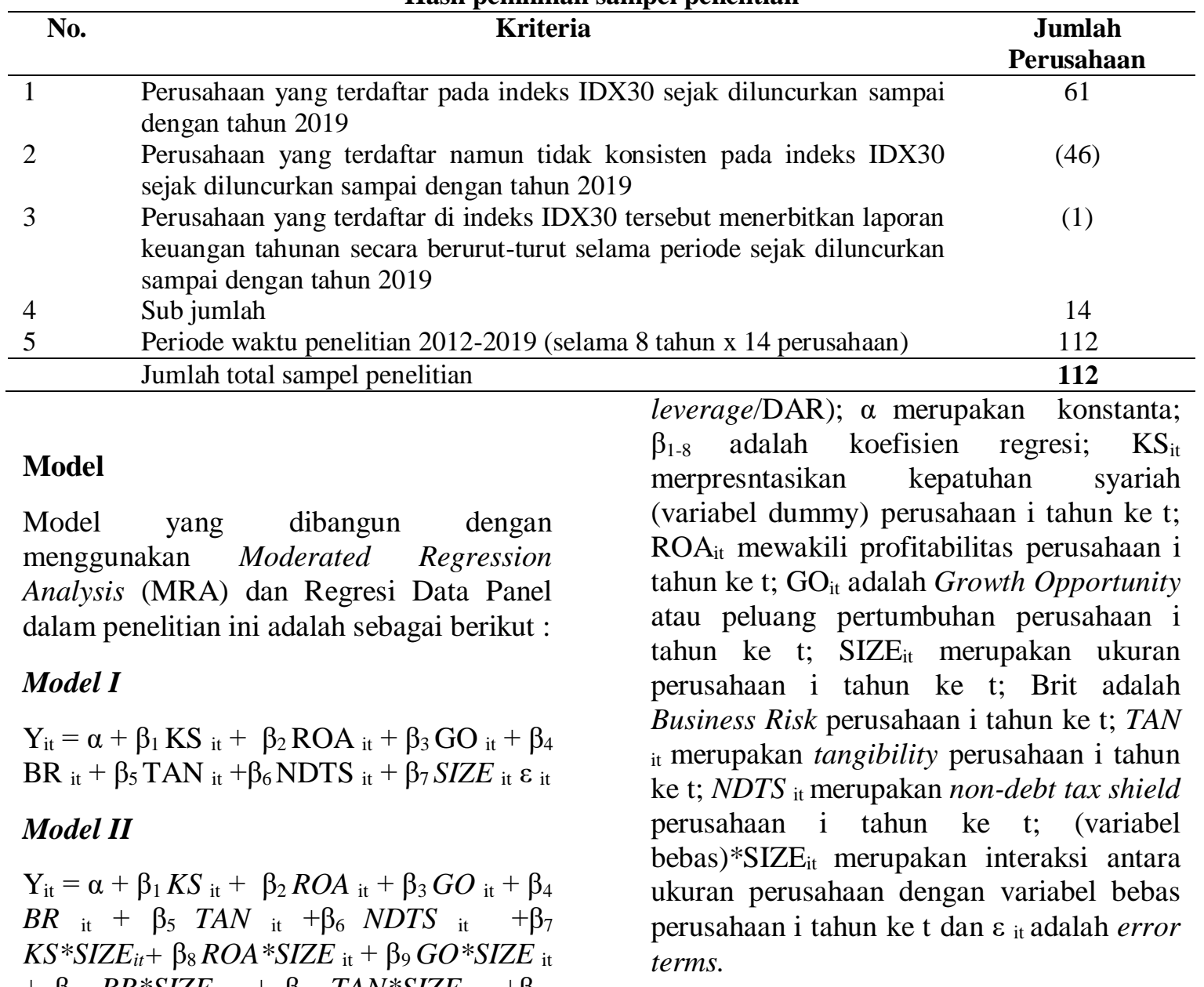

$N D T S * S I Z E_{\text {it }}+\varepsilon_{\text {it }}$

Dari persamaan diatas, Y merepresentasikan struktur modal (book

Tabel 2

Definisi Operasional Variabel

\begin{tabular}{lllc}
\hline No & Variabel & Definisi & Pengukuran \\
\hline $\mathbf{1}$ & $\begin{array}{l}\text { Book } \\
\text { Leverage }\end{array}$ & Rasio total hutang terhadap total aset & $\frac{\text { Total Hutang }}{\text { Total aktiva }} \times 100 \%$ \\
& & (Buferna, et al, 2005) \\
\hline $\mathbf{2}$ & $\begin{array}{l}\text { Kepatuhan } \\
\text { Syariah }\end{array}$ & $\begin{array}{l}\text { Variabel dummy ini digunakan untuk } \\
\text { membandingkan tingkat leverage di antara } \\
\text { perusahaan yang patuh syariah dengan }\end{array}$ & $\begin{array}{l}\text { Variabel dummy yang nilainya sama } \\
\text { dersebut sesuai dengan syariah dan 0 } \\
\text { jika sebaliknya (Alnoria dan }\end{array}$ \\
\hline
\end{tabular}




\begin{tabular}{|c|c|c|c|}
\hline & & perusahaan non-syariah & Alqahtani , 2019) \\
\hline 3 & Profitabilitas & $\begin{array}{l}\text { Rasio yang menunjukkan hasil (return) atas } \\
\text { jumlah aktiva yang digunakan dalam } \\
\text { perusahaan }\end{array}$ & $\begin{array}{l}\frac{\text { Laba Bersih setelah pajak }}{\text { Totak aktiva }} \times 100 \%( \\
\text { (Deesomsak et al., 2004) }\end{array}$ \\
\hline 4 & $\begin{array}{l}\text { Growth } \\
\text { opportunity }\end{array}$ & $\begin{array}{l}\text { Gambaran peluang pertumbuhan } \\
\text { perusahaan dimasa yang akan datang. } \\
\text { Variabel ini diukur dengan menggunakan } \\
\text { persentase perubahan total asset }\end{array}$ & $\begin{array}{l}\% \text { perubahan Total asset (Buferna et } \\
\text { al, 2005; Hossain dan Ali, 2012). }\end{array}$ \\
\hline 5 & $\begin{array}{l}\text { Business } \\
\text { Risk }\end{array}$ & $\begin{array}{l}\text { Volatilitas laba yang dihadapi oleh } \\
\text { perusahaan }\end{array}$ & $\begin{array}{l}\text { Standar Deviasi perubahan Laba } \\
\text { operasi (Titman dan Wessels, 1988) }\end{array}$ \\
\hline 6 & Tangibilitas & $\begin{array}{l}\text { Gambaran besarnya fixed assets yang bisa } \\
\text { digunakan sebagai jaminan dalam } \\
\text { memperoleh utang }\end{array}$ & $\begin{array}{l}\frac{\text { Total Aset Tetap }}{\text { Total Aset }} \times 100 \% \\
\text { (Hossain dan Ali, 2012) }\end{array}$ \\
\hline 7 & $\begin{array}{l}\text { Non-debt } \\
\text { tax shield } \\
\text { (NDTS) }\end{array}$ & $\begin{array}{l}\text { Penghematan pajak yang bukan bersumber } \\
\text { dari hutang merupakan penghematan pajak } \\
\text { yang bukan berasal dari bunga pinjaman } \\
\text { yang dibayarkan (Krisnanda dan Wiksuana, } \\
\text { 2015) }\end{array}$ & $\frac{\text { Depresiasi }}{\text { Total Aset }}$ (Sheikh dan Wang, 2011) \\
\hline 8 & Size & $\begin{array}{l}\text { Variabel Moderasi : Gambaran akan besar } \\
\text { kecilnya ukuran perusahaan. Dalam } \\
\text { penelitian ini size diukur dengan Ln dari } \\
\text { Total Aset. }\end{array}$ & $\begin{array}{l}\text { Ln(Total Aset) (Tang dan Jang, } \\
\text { 2007) }\end{array}$ \\
\hline
\end{tabular}

\section{Teknik Analisis}

Analisis pada penelitian ini akan menganalisis model I dengan regresi data panel melalui pendekatan OLS (common effect), fixed effect dan random effect. Dari ketiga pendekatan itu akan dipilih mana yang terbaik menggunakan uji Chow, Uji Hausman dan Uji Langrage Multiplier. Model II akan dianalisis dengan Moderated
Regression Analysis (MRA) pada aplikasi Eviews.

\section{HASIL DAN PEMBAHASAN}

Dari hasil pemilihan sampel dengan teknik pusposive sampling diperoleh sebanyak 14 perusahaan sebagai sampel penelitian seperti tabel 1 dengan periode waktu penelitian sejak diluncurkannya indeks IDX30 pada taun 2012 sampai dengan 2019, sehingga diperoleh data penelitian sebanyak 112 data. Deskripsi statistik dapat dilihat pada tabel 3 .

Tabel 3

Deskripsi Statistik

\begin{tabular}{lllllllll}
\hline & DAR & KS & ROA & BR & GO & TAN & NDTS & SIZE \\
\hline Mean & 0.535 & 0.625 & 0.097 & 14.374 & 10.365 & 25.597 & 18.202 & 18.825 \\
Median & 0.490 & 1.000 & 0.063 & 14.257 & 9.680 & 25.305 & 17.380 & 18.315 \\
Maximum & 0.880 & 1.000 & 0.465 & 19.178 & 92.200 & 70.920 & 52.100 & 22.800 \\
Minimum & 0.130 & 0.000 & 0.013 & 11.250 & -33.040 & 0.360 & 0.710 & 15.670 \\
Std. Dev. & 0.244 & 0.486 & 0.099 & 1.576 & 12.999 & 20.003 & 13.570 & 1.768 \\
Skewness & 0.081 & -0.516 & 2.007 & 0.897 & 2.954 & 0.384 & 0.237 & 0.420 \\
Kurtosis & 1.774 & 1.267 & 6.707 & 4.477 & 21.174 & 2.197 & 2.079 & 2.290 \\
Observations & 112 & 112 & 112 & 112 & 112 & 112 & 112 & 112 \\
\hline
\end{tabular}


Dari semua variabel penelitian hanya GO (growth opportunitiesi) yang memiliki nilai standar deviasi melebihi nilai rata-rata (mean) yaitu sebesar 12.99 dibandingkan 10.36. Hal ini mengindikasikan bahwa data pada variabel tersebut kurang menyebar secara merata. Untuk variabel lain secara statistik telah menunjukkan persebaran data yang cukup baik.

Tabel 4

Koefisien Matriks Korelasi Pearson

\begin{tabular}{|c|c|c|c|c|c|c|c|}
\hline Correlation & KS & ROA & BR & GO & TAN & NDTS & SIZE \\
\hline KS & 1 & & & & & & \\
\hline ROA & 0.436863 & 1 & & & & & \\
\hline $\mathrm{BR}$ & -0.2167 & -0.24923 & 1 & & & & \\
\hline GO & 0.091377 & -0.03624 & -0.05345 & 1 & & & \\
\hline TAN & 0.621659 & 0.601523 & -0.33342 & 0.013918 & 1 & & \\
\hline NDTS & 0.656424 & 0.229662 & -0.08713 & -0.04221 & 0.681669 & 1 & \\
\hline SIZE & -0.4848 & -0.54763 & 0.793734 & -0.01518 & -0.62931 & -0.4227 & 1 \\
\hline
\end{tabular}
menunjukkan tidak ada yang melebihi

Tabel 5

Hasil Uji Chow , Uji Hausman dan Uji LM

\begin{tabular}{lllllll}
\hline \multirow{2}{*}{ Models } & Chow Test & & Hausman Test & \multicolumn{3}{c}{ Lagrange Multiplier Tests } \\
& statistic & prob. & statistic & prob. & statistic & prob. \\
\hline Model I & 299.71 & 0.0000 & 9.04 & 0.24 & 225.58 & 0.0000 \\
Model II & 314.53 & 0.0000 & 12.94 & 0.37 & 189.89 & 0.0000 \\
\hline
\end{tabular}

Tabel 5 menampilkan hasil pemilihan dari model terbaik yang digunakan untuk intepretasi hasil regresi. Model I dan II kompak memilih model Random Effect sebagai model terbaik dalam regresi panel ini. Berdasarkan Uji Chow dimana model I dan II dengan hasil yang sama menunjukkan probabilitas < 5\% yaitu sebsear 0,0000, maka kita harus menerima bahwa fixed effect lebih baik daripada common effect. Selanjutnya, dilakukan Uji
Hausman, dimana hasilnya model I dan II masing-masing probabilitasnya adalah 0,24 dan 0,37 yang nilai tersebut lebih besar dari 0,05, maka random effect lebih baik daripada fixed effect. Terkahir dalam pemilihan model data panel, dilakukan Uji Langrange Multiplier (LM), dimana hasilnya menunjukkan bahwa probabilitas semua model dibawah 0,05 , hal ini menyimpulkan bahwa model terbaik adalah random effect.

Tabel 6. Hasil Regresi Random Effect Model I dan II

\begin{tabular}{lllllllll}
\hline Panel A & & \multicolumn{7}{c}{ Panel B } \\
\hline Variable & Coefficient & Std. Error & t-Statistic & Prob. & Coefficient & Std. Error & t-Statistic & Prob. \\
\hline C & 0.0978 & 0.2161 & 0.4525 & 0.6519 & 0.6082 & 0.0990 & 6.1439 & 0.0000 \\
KS & -0.0052 & 0.0277 & -0.1872 & 0.8519 & -0.1375 & 0.1886 & -0.7289 & 0.4678 \\
ROA & -0.6548 & 0.1064 & -6.1533 & $0.0000^{* * *}$ & -0.1524 & 0.9016 & -0.1690 & 0.8661 \\
BR & 0.0095 & 0.0052 & 1.8285 & $0.0703^{*}$ & 0.0293 & 0.0170 & 1.7184 & $0.0888^{*}$
\end{tabular}




\begin{tabular}{|c|c|c|c|c|c|c|c|c|}
\hline GO & 0.0002 & 0.0003 & 0.5744 & 0.5669 & -0.0015 & 0.0051 & -0.3024 & 0.7630 \\
\hline TAN & 0.0008 & 0.0006 & 1.2836 & 0.2021 & -0.0162 & 0.0057 & -2.8373 & $0.0055^{* * * *}$ \\
\hline NDTS & -0.0046 & 0.0008 & -5.7448 & $0.0000 * * *$ & -0.0238 & 0.0096 & -2.4869 & $0.0146 * *$ \\
\hline SIZE & 0.0227 & 0.0103 & 2.2128 & $0.0291 * *$ & & & & \\
\hline SIZE_KS & & & & & 0.0088 & 0.0098 & 0.8945 & 0.3732 \\
\hline SIZE_ROA & & & & & -0.0004 & 0.0005 & -0.7834 & 0.4352 \\
\hline SIZE_BR & & & & & -0.0011 & 0.0009 & -1.2542 & 0.2127 \\
\hline SIZE_GO & & & & & 0.0081 & 0.0275 & 0.2938 & 0.7695 \\
\hline SIZE_TAN & & & & & 0.0829 & 0.0286 & 2.8975 & $0.0046 * * *$ \\
\hline SIZE_NDTS & & & & & 0.1043 & 0.0516 & 2.0236 & $0.0457 * *$ \\
\hline \multicolumn{5}{|c|}{ Weighted Statistics } & \multicolumn{4}{|c|}{ Weighted Statistics } \\
\hline $\begin{array}{l}R \text {-squared } \\
\text { Adjusted } R \text { - } \\
\text { squared }\end{array}$ & $\begin{array}{l}0.440 \\
0.402\end{array}$ & & & & $\begin{array}{l}R \text {-squared } \\
\text { Adjusted } R \text { - } \\
\text { squared }\end{array}$ & $\begin{array}{l}0.537 \\
0.480\end{array}$ & & \\
\hline $\begin{array}{l}F \text {-statistic } \\
\text { Prob(F- } \\
\text { statistic })\end{array}$ & 11.656 & & & & $\begin{array}{l}F \text {-statistic } \\
\text { Prob(F- } \\
\text { statistic) }\end{array}$ & 9.555 & & \\
\hline
\end{tabular}

Tabel 6 menunjukkan hasil regresi random effect dengan dua panel, yakni panel A dan panel B. Panel A merupakan regresi yang belum memasukkan ukuran perusahaan sebagai variabel moderasi, sedangkan panel $\mathrm{B}$ adalah regresi yang memasukkan ukuran perusahaan sebagai variabel moderasi. Hasilnya menunjukkan bahwa adjusted $R$ squared panel A sebesar 0,402 atau 40,2 \% model mampu menjelaskan hubungan antara variabel independen dengan variabel dependen. Pada panel $\mathrm{B}$, angka adjusted $R$ squared sebesar 0,537 atau $53,7 \%$ model mampu menjelaskan hubungan antara variabel independen dengan variabel dependen.

\section{Diskusi Model I}

Berdasarkan hasil empiris tabel 6 pada panel A, Model I ditemukan bahwa profitabilitas berpengaruh negatif terhadap book leverage pada taraf kepercayaan < $1 \%$, hal ini menegaskan bahwa perusahaan membiayai kegiatan usahanya mengikuti pola teori pecking order. Perusahaan dengan profitabilitas yang tinggi, dalam penelitian ini tidak akan memperbesar porsi hutang mereka dalam membiayai jalannya kegiatan usahanya. Penggunaan laba ditahan adalah opsi yang sesuai dengan teori pecking order. Hasil ini sejalan dengan penelitian yang dilakukan oleh Toy et al (1974), Titman dan Wessels (1988), Rajan dan Zingales (1995), Wald (1999), Booth et al (2001), Chen (2004), Bauer (2004), Viviani (2008) dan Öztekin (2015).

Variabel perisai pajak selain hutang (NDTS) juga berpengaruh signifikan dengan arah negatif terhadap book leverage pada tingkat kepercayaan $<1 \%$, hasil ini juga menegaskan bahwa perusahaan dengan kepemilikan perisai pajak selain hutang yang tinggi akan menurunkan tingkat hutang pada perusahaan tersebut. Alasannya, perusahaan telah mendapatkan benefit perisai pajak dari segi depresiasi dan amortisasi, jadi perusahaan tidak perlu lagi melebarkan hutangnya untuk menghindari pajak. Penelitian ini mendukung penelitian yang telah dilakukan oleh Wald (1999), Deesomsak et al. (2004) dan Viviani (2008) pada hutang jangka pendek.

Hubungan yang positif dan signifikan pada taraf $<5 \%$, dibuktikan pada variabel ukuran perusahaan (size) terhadap book leverage. Temuan ini konsisten dengan prediksi pada teori trade off, bahwasannya perusahaan dengan ukuran yang besar memiliki risiko yang rendah, kecil kemungkinan untuk bangkrut dan lebih terdiversifikasi. Perusahaan dengan ukuran 
yang besar lebih memilih menggunakan opsi hutang daripada pembiayaan dari ekuitasnya. Penelitian ini mendukung penelitian oleh Bauer (2004), Chen (2004), Deesomsak et al (2004) dan Sheikh dan Wang (2011). Namun, hasil penelitian ini bertentangan dengan yang dilakukan oleh Titman dan Wessels (1988).

Risiko bisnis (BR) ditemukan memiliki pengaruh positif signifikan pada level kepercayaan $<10 \%$ terhadap book leverage. Pada teori pecking order dan trade off, memiliki pendapat bahwa risiko bisnis atau beberapa menyebut volatilitas laba, memiliki pengaruh yang negatif terhadap leverage perusahaan. Hasil temuan dari variabel risiko bisnis ini cukup mengejutkan, karena bertentangan dengan teori-teori diatas. Kondisi ini bisa terjadi karena banyak hal, misalnya variasi suku bunga, kebijakan moneter dari Bank Indonesia, situasi politik dan keadaan ekonomi masa penelitian turut mempengaruhi (Sheikh dan Qureshi, 2017). Namun, terlepas dari dua pandangan teori diatas, hasil empiris menunjukkan hasil yang beragam. Hubungan negatif signifikan ditemukan oleh Scott (1977), Bradley et al (1984), Titman \& Wessels (1988), De Miguel \& Pindado (2001), Chen (2004) dan Furi dan Saifudin (2012). Penlitian ini sejalan dengan penelitian oleh Esperanca et al (2003) dan Malinic et al (2013) yang menyatakan bahwa risiko bisnis memiliki hubungan positif terhadap leverage perusahaan.

Penelitian ini tidak memberikan temuan signifikan pada variabel growth opportunities, kepatuhan syariah dan tangibilitas. Kepatuhan syariah pada sampel penelitian ini, dapat diartikan belum mewakili untuk dijadikan pertimbangan dalam menentukan struktur modal yang optimal, karena dengan arah koefisien yang negatif namun signifikansi diatas $10 \%$. Growth opportunities dan tangibilitas, memiliki signifikansi diatas $10 \%$ dengan arah hubungan positif, juga tidak memberikan pengaruh yang signifikan. Temuan peluang pertumbuhan yang tidak signifikan sejalan dengan penelitian Titman \& Wessels (1988) dan Sheikh dan Wang (2011). Sedangkan temuan tangibilitas yang tidak signifikan sejalan dengan penelitian Buferna et al (2005) dan Ibrahim et al (2015).

\section{Diskusi Model II}

Berdasarkan tabel 6 pada panel B, peneliti berfokus pada interaksi antara variabel moderasi (size) dengan variabel independen. Dari hasil regresi panel B pada tabel 6, hanya variabel interkasi perisai pajak non hutang dan tangibilitas dengan ukuran perusahaan yang memiliki pengaruh signifikan terhadap book leverage.

Interaksi antara perisai pajak non hutang dengan ukuran perusahaan dengan signifikansi $<5 \%$ dan memiliki arah positif, memiliki arti bahwa ukuran perusahaan mampu memoderasi dengan sifat menguatkan hubungan antara perisai pajak non hutang dengan leverage perusahaan. Perusahaan dengan ukuran yang besar, meskipun memiliki opsi perisai pajak dari selain hutang yang tinggi, mereka semakin meningkatkan leverage perusahaan untuk membiayai kegiatan usahanya. Hal ini, sesuai dengan teori trade off, bahwa perusahaan besar memiliki risiko kebangkrutan yang rendah. Perusahaan berukuran besar dengan didukung dengan perisai pajak non hutang (yang berasal dari depresiasi) yang besar, akan semakin memanfaatkan benefit dari penghindaran pajak dari tingginya penggunaan dana dari hutang, karena perusahaan mampu menunjukkan bahwa jaminan likuidasi pada pembiayaan hutang cukup kuat, sehingga penggunaan dana dari sumber hutang yang besar tidak menjadi masalah pada perusahaan berukuran besar.

Ukuran perusahaan juga mampu memoderasi dengan sifat menguatkan pada hubungan antara tangibilitas dengan leverage perusahaan. Pada tabel 6 panel B, dengan signifikansi kurang dari $1 \%$, membuktikan bahwa ukuran perusahaan mampu memoderasi hubungan antara tangibilitas dengan leverage perusahaan. Titman and Wessels (1988), Rajan and Zingales ( 1995 dan Bevan and Danbolt (2001) menyatakan perusahaan berukuran besar dengan aset tetap yang memadai maka penggunaan dana dari sumber hutang adalah pilihan yang menarik. Alasannya 
adalah perusahaan dengan ukuran besar dan struktur aset tetap yang melimpah, maka menjadi jaminan bahwa kolateral mereka mampu untuk menutup hutang-hutang jika terjadi kesulitan keuangan dan dapat mengurangi biaya agensi (agency cost) dari hutang. Rasa percaya diri perusahaan tersebut semakin mendorong perusahaan untuk menggunakan hutang sebagai sumber pendanaan kegiatan usahanya.

Variabel lainnya seperti risiko bisnis, peluang pertumbuhan, kepatuhan syariah dan profitabilitas terbukti tidak dimoderasi oleh ukuran perusahaan. Berapapun ukuran perusahaan tidak mempengaruhi hubungan antara variabel tersebut terhadap leverage perusahaan:

\section{KESIMPULAN}

Tujuan dari penelitian ini adalah menguji faktor-faktor apa saja yang memiliki pengaruh terhadap leverage perusahaan. Dari uji hipotesis yang dilakukan, variabel profitabilitas (ROA), perisai pajak non hutang (NDTS) berpengaruh negatif signifikan terhadap leverage perusahaan, pengaruh positif didapatkan dari variabel risiko bisnis (BR) dan ukuran perusahaan (SIZE), sedangkan kepatuhan syariah (KS), tangibilitas (TAN) dan growth opportunities (GO) tidak berpengaruh terhadap leverage perusahaan.

Perusahaan yang masuk dalam indeks IDX30 jika dilihat dari hasil arah kofisien profitabilitas lebih condong untuk menganut teori pecking order. Dimana, perusahaan dengan profitabilitas yang tinggi maka akan mengurangi porsi hutang dalam struktur modalnya, karena mereka lebih memanfaatkan laba dari perusahaan tersebut terlebih dahulu. Namun, ketika melihat arah koefisien dari non debt tax shiled (NDTS) atau perisai hutang non pajak maka lebih condong ke teori trade off. Perusahaan yang memiliki perisai hutang non pajak yang tinggi dapat menurunkan besaran hutang perusahaan tersebut. Hasil temuan variabel risiko bisnis (BR) berpengaruh positif signifikan terhadap leverage perusahaan pada margin of error $10 \%$ bertentangan dengan dua teori utama dalam struktur modal, beberapa kondisi dapat menyebabkan hal ini seperti variasi suku bunga, kebijakan moneter dan situasi polik ekonomi suatu negara.

Ukuran perusahaan hanya mampu memoderasi variabel tangibilitas dan non debt tax shield (NDTS), semakin besar ukuran sebuah perusahaan didukung dengan aset tetap yang memadai dan perisai pajak non hutang (NDTS) yang tinggi, maka perusahaan semakin berani untuk meningkatkan leverage perusahaan untuk membiayai kegiatan usahanya. Jaminan perusahaan dan benefit dari NDTS atas pajak perusahaan, semakin membuat percaya diri perusahaan untuk berhutang.

Penelitian ini memang tidak jauh dari keterbatasan, tentu dengan masih rendahnya nilai adj $R$ square, maka memungkinkan masih ada faktor lain yang turut mempengaruhi penentuan struktur modal, seperti inflasi dan median leverage industri. Penelitian selanjutnya dapat mengembangkan ke arah sana.

\section{DAFTAR PUSTAKA}

Ahmad, Noryati \& Azhar, Noor. 2015. Investigating of Shariah Compliant Companies Capital Structure Determinants. Advanced Science Letters.21. 1986-1989. 10.1166/asl.2015.6180.

Akhtar, S., \& Oliver, B. 2009. Determinants of capital structure for Japanese multinational and domestic corporations. International Review of Finance, $\quad 9(1-2), \quad 1-26$. https://doi.org/10.1111/irfi.2009.9.iss ue-1-2

Alnori, F., \& Alqahtani, F. 2019. Capital structure and speed of adjustment in non-financial firms: Does sharia compliance matter? Evidence from Saudi Arabia. Emerging Markets Review, 39, 50-67.

Booth, L., Aivazian, V., Demiguc-Kunt, A., \& Maksimovic, V. 2001. Capital structures in developing countries. Journal of Finance, 56(1), 87-130.

Bevan, A. A., \& Danbolt, J. 2001. On the determinants and dynamics of UK capital structure.

Buferna, F. M., Bangassa, K., \& Hodgkinson, L. 2005. Determinants of capital structure: evidence from 
Libya (Vol. 8). University of Liverpool.

Chen, J. J. 2004. Determinants of capital structure of Chinese-listed companies. Journal of Business research, 57(12), 1341-1351.

DeAngelo, H., \& Masulis, R. W. 1980. Optimal capital structure under corporate and personal taxation. Journal of Financial Economics, $8(1)$, 3-29. https://doi.org/10.1016/0304405X(80)90019-7

Deesomsak, R., K. Paudyal, dan G. Pescetto. 2004. The determinants of capital structure: evidence from the Asia Pacific region. Journal of Multinational Finance Management 14(4-5): 387-405. http://doi.org/10.1016/j.mulfin.2004. 03.001.

De Miguel, A., \& Pindado, J. 2001. Determinants of capital structure: new evidence from Spanish panel data. Journal of corporate finance, 7(1), 77-99.

Esperanca, J. P., Gama, A. P. M., \& Gulamhussen, M. A. 2003. Corporate debt policy of small firms: an empirical (re) examination. Journal of Small Business and Enterprise Development.

Farooq, O., \& Tbeur, O. 2013. Dividend policies of shariah-compliant and non-shariah-compliant firms: evidence from the MENA region. International Journal of Economics and Business Research, 6(2), 158172.

Fischer, E. O., Heinkel, R., \& Zechner, J. 1989. Dynamic capital structure choice: Theory and tests. The Journal of Finance, 44(1), 19-40. https://doi.org/10.1111/j.15406261.1989.tb02402.x

Furi, V. R., dan Saifudin. 2012. Faktor Faktor yang Mempengaruhi Struktur Modal ( Studi Empiris Pada Perusahaan Manufaktur yang Terdaftar di BEI Tahun (2009 - 2010 ). JURAKSI 1(2): 49-62.

Hatzinikolaou, D., Katsimbris, G. M., \& Noulas, A. G. 2002. Inflation uncertainty and capital structure: Evidence from a pooled sample of the Dow-Jones industrial firms. International Review of Economics \& Finance, $\quad 11(1), \quad 45-55$. https://doi.org/10.1016/S10590560(01)00085-5

Hossain, F., \& Ali, A. 2012. Impact of firm specific factors on capital structure decision: an empirical study of Bangladeshi Companies. International Journal of Business Research and Management, 3(4), 163-182.

Ilyukhin, Evgeny, The Determinants of Capital Structure: Evidence from Russia (May 25, 2017). http://dx.doi.org/10.2139/ssrn.29742 $\underline{13}$

Jensen, M. C., \& Meckling, W. H. 1979. Theory of the firm: Managerial behavior, agency costs, and ownership structure. In Economics social institutions (pp. 163-231). Springer, Dordrecht.

Kasmir. Analisis Laporan Keuangan. Edisi Pertama, Cetakan Ketujuh. Jakarta: PT. Rajagrafindo Persada. Tahun 2014.

Malinić, D., Denčić-Mihajlov, K. and Ljubenović, E. 2013, "The determinants of capital structure in emerging capital markets: evidence from Serbia“, European Research Studies, vol. 16, № 2, pp. 98-119.

Milton, H., \& Raviv, A. 1991. The theory of capital structure. Journal of Finance, 46(1), 297-355.

Modigliani, F., \& Miller, M. H. 1958. The cost of capital, corporation finance and the theory of investment. The American Economic Review, 261297.

Modigliani, F., \& Miller, M. H. 1963. Corporate income taxes and the cost of capital: A correction. The American Economic Review, 433443.

Myers, S. C. 1977. Determinants of corporate borrowing. Journal of Financial Economics, 5(2), 147-175. https://doi.org/10.1016/0304405X(77)90015-0 
Myers, S. C. 1984. The capital structure puzzle. The Journal of Finance, 39(3), 574-592. https://doi.org/10.1111/j.15406261.1984.tb03646.x

Myers, S. C., \& Majluf, N. S. 1984. Corporate financing and investment decisions when firms have information that investors do not have. Journal of Financial Economics, 13(2), 187-221.

Myers, S. C. 2001. Capital structure. Journal of Economic perspectives, 15(2), 81-102.

Naz, I., Shah, S. M. A., \& Kutan, A. M. 2017. Do managers of shariacompliant firms have distinctive financial styles?. Journal of International Financial Markets, Institutions and Money, 46, 174-187.

Öztekin, Ö. 2015. Capital structure decisions around the world: which factors are reliably important?. Journal of Financial and Quantitative Analysis, 50(3), 301323.

Rajan, R. G., \& Zingales, L. 2003. The great reversals: The politics of financial development in the twentieth century. Journal of Financial Economics, 69(1), 5-50. https://doi.org/10.1016/S0304405X(03)00125-9

Sahudin, Z., Ismail, Z., Sulaiman, S., Rahman, H. A., \& Jaafar, M. N. 2019. Capital Structure Determinants of Shariah-compliant Firms. Journal Of Emerging Economies and Islamic Research, 7(1), 65-75.

Scott, H. 1977. Bankruptcy, Secured Debt, and Optimal Capital Structure. The Journal of Finance 32(1): 1-19. Retrieved from http://www.jstor.org/stable/ 2326898. Diakses tanggal 3 April 2014.

Sheikh, N. and Qureshi, M. 2017. "Determinants of capital structure of Islamic and conventional commercial banks: Evidence from Pakistan", International Journal of Islamic and Middle Eastern Finance and Management, Vol. 10 No. 1, pp. 24-41.
Sheikh, N. A., \& Wang, Z. 2011. Determinants of capital structure: An empirical study of firms in manufacturing industry of Pakistan. Managerial Finance, 37(2), 117133.

https://doi.org/10.1108/03074351111 103668

Sukor, M. E. A., Halim, A. A., \& Bacha, O. I. 2018. The capital structure decisions of Shariah compliant and non-compliant firms: Evidence from Malaysia. 20th Malaysian Finance Association Conference 2018: Innovative Ecosystem for Financial Revolution.

Tang, C. H. H., \& Jang, S. S. 2007. Revisit to the determinants of capital structure: A comparison between lodging firms and software firms. International Journal of Hospitality Management, 26(1), 175187.

Titman, S., \& Wessels, R. 1988. The determinants of capital structure choice. The Journal of Finance, 43(1), 1-19. https://doi.org/10.1111/j.15406261.1988.tb02585.x

Toy, N., Stonehill, A., Remmers, L. and Beekhuisen, T. 1974, "A comparative international study of growth, profitability, and risk as determinants of corporate debt ratios in the manufacturing sector", The Journal of Financial and Quantitative Analysis, vol. 9, № 5, pp. 875-886.

Viviani, J. L. 2008. Capital structure determinants: an empirical study of French companies in the wine industry. International journal of wine business research.

Wald, J. K. 1999. How firm characteristics affect capital structure: an international comparison. Journal of Financial research, 22(2), 161-187.

Yildirim, R., Masih, M., \& Bacha, O. I. 2018. Determinants of capital structure: evidence from Shari'ah compliant and non-compliant firms. Pacific-Basin Finance Journal, 51, 198-219 
